\title{
Pengaruh musim terhadap kejadian pneumonia pada balita di Kabupaten Pelalawan
}

\author{
Yessi Harnani ${ }^{1^{*}}$, Rasoel Hamidy ${ }^{2}$, Sukendi ${ }^{3}$, Dedi Afandi ${ }^{4}$ \\ ${ }^{1}$ STIKes Hang Tuah Pekanbaru \\ ${ }^{2,3}$ Program Doktor Ilmu Lingkungan Program Pascasarjana Universitas Riau \\ ${ }^{4}$ Fakultas Kedokteran Universitas Riau \\ *Koresponden E-mail: yessiharnani@gmail.com
}

(Diterima: 15 November 2021|Disetujui: 05 Januari 2022 |Diterbitkan: 31 Januari 2022)

\begin{abstract}
Pneumonia is a type of lower respiratory tract infection and the main cause of under-five mortality, especially in developing countries, with a mortality rate of 3 million each year. Pneumonia cases in children under five in Pelalawan Regency are quite high, namely 72.8\% in 2018. Pneumonia is also influenced by climatic conditions and seasons. Parasites and disease vectors are very sensitive to climatic factors, especially temperature, humidity, and rainfall. The purpose of this study was to determine the effect of season on the incidence of pneumonia in children under five in Pelalawan District. This type of research is analytic observational with a cross sectional approach. The study population was all patients with pneumonia under five who were recorded in the registration of 12 Puskesmas in Pelalawan Regency in 2018-2019. The research sample uses total sampling. Data analysis uses the Vector Autorgressive (VAR) method on time series data with time level being monthly data. The results showed that the trend of the number of pneumonia cases fluctuated approximately every 2 months, this was caused by the influence of the season, namely the rainy season and dry season. Mostly in the rainy season the number of pneumonia cases tends to experience an increasing trend. Based on statistical tests, it is known that seasonal variables (rainfall, rainy days, humidity and temperature) have no significant effect on the incidence of pneumonia in children under five, but the $R$ Square value in the modeling above is quite good, namely 0.655 , meaning that $65.5 \%$ of the diversity of pneumonia cases can be explained. by these variables while the rest is explained by other variables outside the model. For this reason, it is hoped that the Puskesmas will campaign for the '5 $\mathrm{M}^{\prime}$ program, especially in the rainy season (opening ventilation, entry of light, entry of air, maintaining house cleanliness and increasing body immunity). It is suggested to the Pelalawan District Health Office to monitor climate factors on an ongoing basis in the context of the program to eradicate pneumonia in children under five.
\end{abstract}

Keywords: pneumonia; toddler; rainy season; dry season

\section{PENDAHULUAN}

Pneumonia adalah penyakit yang menyerang paru-paru dan ditandai dengan batuk dan kesusahan bernafas (WHO, 2016). Penyakit ini menjadi penyebab utama morbiditas dan mortalitas penyakit infeksi di seluruh dunia dengan angka kejadian sebesar 18,8 miliar kasus dan jumlah kematian sebesar 4 juta orang setiap tahunnya (Kemenkes RI, 2011). Penyakit ini terjadi di seluruh wilayah mulai dari negara miskin, negara berkembang sampai negara maju. Seperti di wilayah Sub Sahara Afrika, China, dan Australia dimana penyebab utama kunjungan masyarakat ke pelayanan kesehatan adalah ISPA (Chen et al., 2012).

Balita merupakan kelompok masyarakat yang paling rentan terhadap penyakit pneumonia. Pada tahun 2015, World Health Organization (WHO) melaporkan hampir $16 \%$ dari 6 juta anak balita meninggal dunia, dari jumlah tersebut disebabkan oleh pneumonia sebagai pembunuh balita nomor 1 di dunia (Geberet et al., 2015). Berdasarkan data dari UNICEF, pada 2015 terdapat kurang lebih 14 persen dari 147.000 anak di bawah usia 5 tahun di Indonesia meninggal karena pneumonia.

Sejumlah agen, seperti bakteri, virus dan jamur merupakan penyebab pneumonia. Streptococcus pneumoniae (S. pneumoniae) adalah penyebab pneumonia terbanyak pada anak-anak (Onozuka \& Chaves , 2014; Honkinen et al., 2012). Pneumonia juga dipengaruhi oleh kondisi iklim dan musim. Parasit dan vektor penyakit sangat peka terhadap faktor iklim, khususnya suhu, kelembaban, dan curah hujan (Kumbasari et al., 2017). Perubahan iklim menimbulkan efek terhadap kesehatan manusia secara langsung maupun tidak langsung, efek langsung berupa efek ekstrim dingin dan panas. Curah hujan yang ekstrim dapat meningkatkan kasus penyakit pneumonia (Ernyasih \& Noor, 2018). Kejadian penumonia sangat erat kaitannya dengan kondisi suhu tinggi dan rendah (Herrera-lara et al., 2013). Hasil penelitian terhadap beberapa negara menunjukkan hubungan yang signifikan kejadian penumonia pada anak dengan kondisi iklim di wilayah tersebut. Kondisi 
iklim yang berbeda dan bervariasi sehingga memberikan pengaruh penyebaran penyakit yang berbeda di setiap negara terutama penyakit menular (Kim et al., 2016).

Kabupaten Pelalawan merupakan salah satu dari dua belas Kabupaten di Propinsi Riau dengan kasus Pneumonia pada balita cukup tinggi, yaitu pada tahun 2018 terdapat 72,8 \% kasus pneumonia pada balita. Secara topografi Kabupaten pelalawan memiliki struktur wilayah daratan rendah dan berbukit-bukit. Kabupaten Pelalawan juga memiliki beberapa pulau besar dan pulau kecil. Secara fisik sebagian wilayah ini merupakan daerah konservasi dengan karakteristik tanah pada bagian tertentu bersifat asam dan merupakan tanah organik, air tanahnya payau, kelembaban dan temperatur udara agak tinggi. Adanya perbedaan ketinggian suatu wilayah akan berpengaruh terhadap perbedaan kondisi iklim (Harnani et al., 2020) (HU, W., Z. Xu \& Tong, 2015).

Untuk mengatasi kejadian pneumonia pada balita yang disebabkan oleh perbedaan kondisi iklim maka perlu dilakukan penelitian untuk mengetahui pengaruh musim terhadap kejadian pneumonia pada balita. Tujuan penelitian ini adalah untuk mengetahui pengaruh musim terhadap kejadian pneumonia pada balita di di Kabupaten Pelalawan Propinsi Riau. Hasil penelitian ini dapat dijadikan sebagai sumber informasi dan acuan dalam membuat program penanganan balita dengan pneumonia.

\section{BAHAN DAN METODE}

Jenis penelitian ini adalah analitik kuantitatif observasional dengan pendekatan cross sectional. Penelitian dilakukan dengan menggunakan data sekunder dari rekapitulasi laporan data bulanan jumlah pneumonia dari seluruh Puskesmas yang ada di Kabupaten Pelalawan dan data laporan bulanan iklim dari Badan Meteorologi, Klimatelogi dan Geofisika (BMKG) yang meliputi curah hujan, hari hujan, kelembaban dan suhu. Populasi penelitian adalah seluruh penderita pneumonia balita yang tercatat di registrasi 12 Puskesmas yang ada di Kabupaten Pelalawan pada tahun 2018-2019. Sampel penelitian menggunakan total sampling. Variabel bebas dalam penelitian ini meliputi kondisi curah hujan, hari hujan, kelembaban dan suhu di dataran tinggi dan dataran rendah di Kabupaten Pelalawan pada tahun 20182019. Instrumen yang digunakan adalah lembar cheklist. Analisis data menggunakan metode Vector Autorgressive (VAR) pada data time series dengan level waktu adalah data bulanan (Sapautra, \& Mirtawati, 2020).

\section{HASIL DAN PEMBAHASAN}

Wilayah Kabupaten Pelawan terletak dibagian timur Propinsi Riau dengan luas 13.256,7 $\mathrm{km}^{2}$ terbagi atas 12 (dua belas) kecamatan (Bandar Sei Kijang, Pangkalan Kerinci, Langgam, Pelalawan, Panglan Kuras, Bunut, Bandar Petalangan, Pangkalan Lesung, Ukui, Kerumutan, Teluk Meranti, Kuala Kampar). Secara topografi Kabupaten Pelalawan terdiri dari daratan, dan perairan. Daratan merupakan perbukitan dan dataran (93\% dataran rendah), sedangkan perairan terdiri dari Sungai, dan laut. Sebagian besar wilayah Kabupaten Pelalawan merupakan daerah rawa dan daerah perkebunan terutama perkebunan kelapa sawit. Sungai Kampar yang meluap akibat hujan terus menerus dapat mengakibatkan banjir, bantaran sungai yang dihuni oleh penduduk berpotensi menjadi sumber penyakit kulit, diare dan lain-lain.

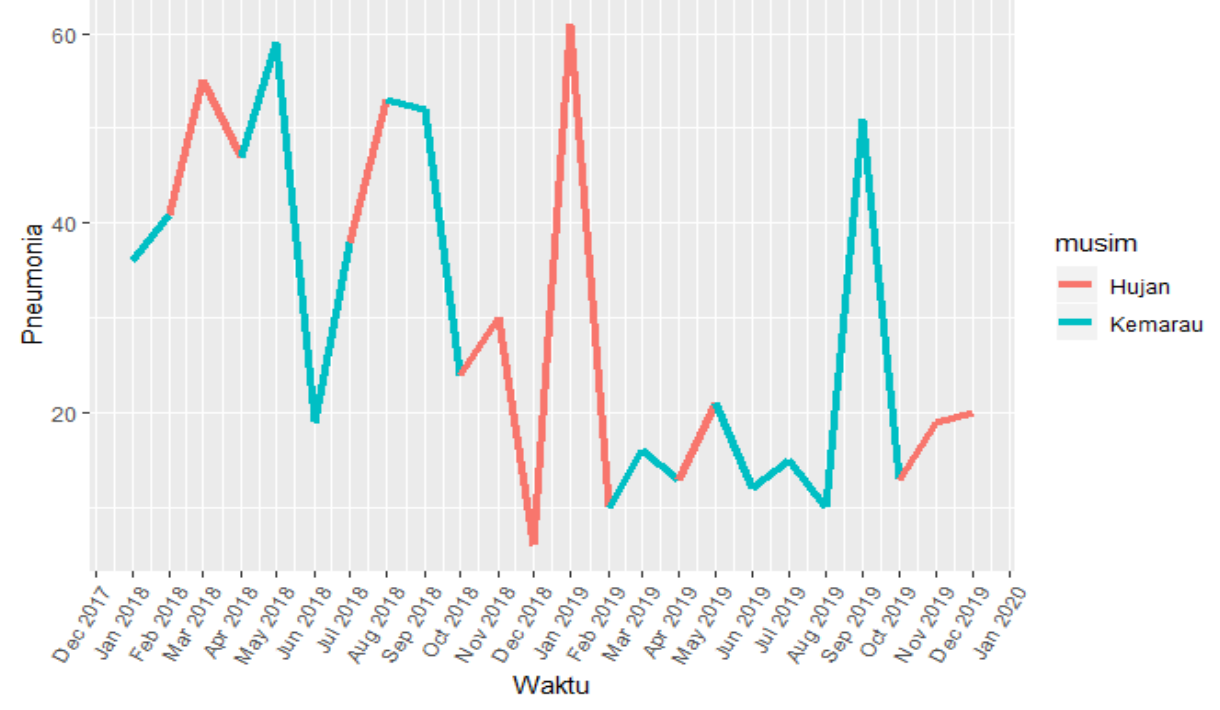

Gambar 1. Grafik Jumlah Kasus Pneumonia di Kabupaten Pelalawan berdasarkan Musim 
Grafik di atas menjelaskan trend kasus Pneumonia di Kabupaten Pelalawan pada Januari 2018 sampai Desember 2019. Terlihat bahwa trend jumlah kasus Pneumonia mengalami fluktuasi kurang lebih setiap 2 bulan, hal ini dikarenakan adanya pengaruh musiman yaitu musim hujan dan kemarau. Sebagian besar pada musim hujan jumlah kasus Pneumonia cenderung mengalami trend yang meningkat, yaitu pada bulan Februari-Maret 2018, Juli-Agustus 2018, Oktober-November 2018, Desember 2018-Januari 2019, April Mei 2019, dan Oktober-Desember 2019. Puncak kenaikan paling signifikan pada musim hujan yaitu pada bulan Desember 2018 - Januari 2019. Sedangkan pada beberapa bulan tertentu, terdapat penurunan jumlah kasus Pneumonia yaitu pada bulan Maret-April 2018, November-Desember 2018, dan Januari-Februari 2019.

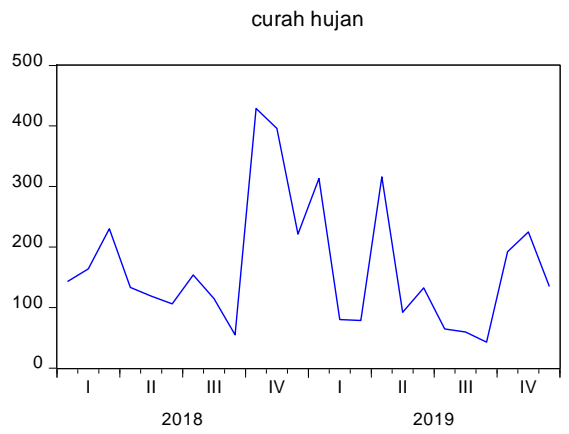

kelembapan

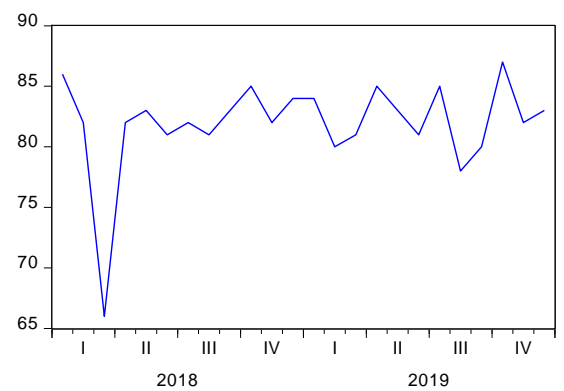

Disisi lain, jumlah kasus Pneumonia pada musim kemarau cenderung berfluktuatif. Jumlah kasus Pneumonia yang mengalami peningkatan yaitu pada bulan Januari-Februari 2018, April-Mei 2018, Juni-Juli 2018, Februari-Maret 2019, dan Juni-Juli 2019. Puncak kenaikan paling signifikan pada musim kemarau yaitu pada bulan Agustus - September 2019. Sedangkan penurunan jumlah kasus Pneumonia yang cukup signifikan adalah pada bulan Mei-Juni 2018, Agustus-Oktober 2018, dan September-Oktober 2019.

Adanya musim kemarau dan penghujan di Kabupaten Pelalawan, mengakibatkan adanya fluktuatif pada jumlah kasus Pneumonia. Oleh karena itu, pada penelitian ini digunakan pendeketan variabel-variabel yang mengukur adanya pola musiman yaitu curah hujan, kelembaban, hari hujan, dan suhu untuk memodelkan jumlah kasus Pneumonia. hari hujan

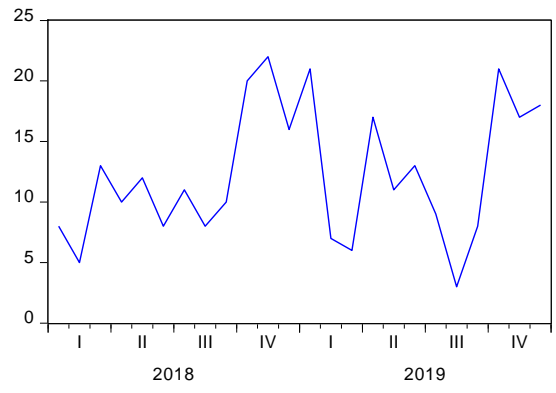

suhu

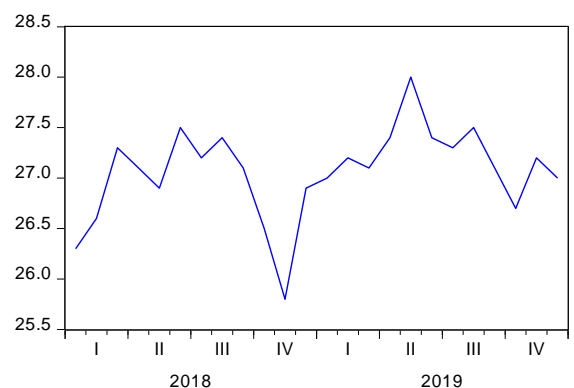

Gambar 2. Grafik variabel musiman di Kabupaten Pelalawan

Pada gambar di atas memperlihatkan trend masing-masing variabel yang mempengaruhi kasus Pneumonia pada Januari 2018 sampai Desember 2019. Pada variabel curah hujan dan hari hujan, peningkatan curah hujan paling tinggi pada bulan Agustus-Desember 2018. Sedangkan pada bulan April - Juli 2019, tingkat curah hujan di Kabupaten Pelalawan cenderung rendah.

Pada variabel kelembaban, penurunan paling signifikan terjadi pada bulan Januari - Maret 2018. Kemudian pada bulan-bulan selanjutnya, tingkat kelembaban di Kabupaten Pelalawan cenderung kosntan di angka 80-85. Pada variabel suhu, terjadi perubahan suhu paling rendah yaitu pada akhir tahun 2018 mencapai sekitar 26 derajat celsius. Pada bulan-bulan selanjutnya, suhu di kabupaten Pelalawan cenderung stabil pada suhu $27-27.5$ derajat celcius.
Selanjutnya dilakukan pemodelan jumlah kasus Pneumonia pada kurun waktu Januari 2018-Desember 2019 di Kabupaten Pelalawan dengan melibatkan variabel musiman, yaitu curah hujan, hari hujan, kelembaban, dan suhu. Pemodelan ini menggunakan metode Vector Autorgressive (VAR) pada data time series dengan level waktu adalah data bulanan.

\section{Pemodelan Vector Autoregressive (VAR)}

Berdasarkan hasil yang disajikan pada output Tabel 1, variabel dikatakan signifikan jika t-statistics > t-tabel $=\left(\frac{\alpha}{2}, n-1\right)=\left(\frac{0.05}{2}, 24-1\right)=2.068$. Dari hasil tabel di atas terlihat bahwa tidak ada nilai t-statistics yang lebih besar dari t-tabel 2.068, sehingga dapat disimpulkan bahwa variabel-variabel di atas tidak berpengaruh signifikan terhadap Kasus Pneumonia di Kabupaten Pelalawan pada periode Januari 2018 sampai 
Desember 2019. Walaupun tidak ada variabel yang signifikan namun nilai $\mathrm{R}$ Square pada pemodelan di atas sudah cukup baik yaitu sebesar 0.655 , artinya sebesar $65.5 \%$ keragaman dari Kasus Pneumonia mampu dijelaskan oleh variabel-variabel tersebut sedangkan sisanya dijelaskan oleh variabel lain di luar model.

Tabel 1. Hasil Pemodelan Vector Autoregressive (VAR)

\begin{tabular}{lrrr}
\hline \multicolumn{1}{c}{ Variabel } & Koefisien & \multicolumn{1}{c}{ Se } & $\begin{array}{c}\text { T-statis- } \\
\text { tics }\end{array}$ \\
\hline C & 1026.373 & 1220.69 & 0.84082 \\
Pneumonia(-1) & 0.127606 & 0.40267 & 0.3169 \\
Pneumonia(-2) & -0.262696 & 0.4664 & 0.56324 \\
Pneumonia(-3) & 0.104483 & 0.33792 & 0.30919 \\
Curah_hujan(-1) & 0.094823 & 0.101 & 0.9388 \\
Curah_hujan(-2) & -0.08698 & 0.11239 & 0.77394 \\
Curah_hujan(-3) & 0.303003 & 0.23719 & 1.27749 \\
Hari_hujan(-1) & -5.545375 & 3.70312 & 1.49749 \\
Hari_hujan(-2) & 1.04621 & 2.28419 & 0.45802 \\
Hari_hujan(-3) & -7.972733 & 6.33304 & 1.25891 \\
Kelembapan(-1) & 1.024356 & 2.2134 & 0.4628 \\
Kelembapan(-2) & 1.626185 & 3.24462 & 0.50119 \\
Kelembapan(-3) & 1.286392 & 1.72362 & 0.74633 \\
Suhu(-1) & -18.91156 & 35.4039 & 0.53417 \\
Suhu(-2) & -15.67985 & 18.7929 & 0.83435 \\
Suhu(-3) & -10.52546 & 26.606 & 0.3956 \\
R square & & 0.655086 & \\
\hline
\end{tabular}

Hasil penelitian menunjukkan ada perbedaan kejadian pneumonia pada balita di Kabupaten Pelalawan di musim kemarau dan musim hujan. Pada musim hujan kasus pneumonia pada balita di Kabupaten Pelalawan cukup tinggi dibandingkan dengan musim kemarau. Pada musim hujan curah hujan cukup tinggi sehingga suhu udara semakin rendah dan tingkat kelembaban udara dalam rumah cukup tinggi hal ini menyebabkan mikroorganisme semakin cepat berkembang.

Hasil uji statistic dalam penelitian ini menunjukkan curah hujan tidak signifikan dengan kejadian pneumonia pada balita di Kabupaten Pelalawan pada tahun 2018-2019. Penelitian ini sejalan dengan penelitian Utami \& Windraswara (2019) bahwa tidak hubungan yang bermakna curah hujan dengan kejadian pneumonia di Kota Semarang tahun 2013-2018 (Utami \& Windraswara, 2019). Berbeda dengan hasil penelitian Kim tahun 2014 menyatakan curah hujan di Papua New Guenea menunjukkan hubungan yang positif dengan kejadian pneumonia pada balita (Kim et al, 2016). Menurut JG Ayres et al.,(2009) dalam jurnalnya mengatakan bahwa peningkatan kasus penyakit infeksi pernafasan kemungkinan dipengaruhi oleh curah hujan ekstrim yang menyebabkan suatu wilayah menjadi dingin. Musim dingin di negara-negara tropis diikuti oleh peningkatan kasus infeksi pernafasan (Ayres, 2009). Peningkatan jumlah bakteri di udara dipengaruhi oleh perubahan curah hujan. Curah hujan yang tinggi menyebabkan suhu udara didalam rumah menjadi rendah dan tingkat kelembaban rumah cukup tinggi, kondisi ini merupakan factor resiko terjadinya pneumonia.

Tingkat kelembaban udara semakin meningkat jika didukung oleh kondisi rumah yang tidak memenuhi standar kesehatan seperti jenis dinding rumah yang terbuat dari kayu, ventilasi udara yang kurang dari $10 \%$ dari luas lantai sehingga sirkulasi udara terganggu, menyebabkan kelembaban tinggi meruapkan media yang baik bagi pertumbuhan bakteri pathogen (Kemenkes RI, 2011; Goel, Hogade \& Karadesai. 2012). Tingkat kelembaban yang tinggi dapat mempengaruhi penurunan daya tahan tubuh seseorang terutama balita yang rentan terhadap penyakit terutama pneumonia (Griffiths, et al. 2016).

Hasil penelitian yang dilakukan oleh Luiz Gustavo Gardinassi et al., (2012), menyatakan bahwa suhu dan kelembaban udara berkorelasi positif dengan virus penyakit pernafasan terhadap anak-anak di bagian tenggara Brasil (Gardinassi, Luiz et al., 2012). Hasil penelitian menunjukkan ketika suhu dan kelembaban udara menurun, virus infeksi saluran pernafasan cenderung meningkat. Ayres dan kawan-kawan (2009) juga mengatakan bahwa curah hujan yang berlebihan akan membuat rumah menjadi lembab, curah hujan tidak menentu dan kebanyakan penderita yang tinggal di kawasan padat penduduk karena sirkulasi dan sanitasi yang kurang baik merupakan penyebab terjadinya penyakit Pernafasan Kronis seperti ISPA (Ayres. 2009).

Pada musim hujan kelembaban udara cukup rendah, sehingga menyebabkan bakteri akan bertahan lebih lama dan dalam kondisi rumah yang tidak dilengkapi ventilasi yang baik, maka akan mempercepat proses penularan penyakit (Gardinassi. Luiz et al., 2012). Salah satu faktor terjadinya penyakit pernafasan adalah kelembaban (Onozuka et al., 2009). Bayi dan balita sangat rentan untuk mengalami infeksi saluran pernafasan. Hasil penelitian terhadap 8 negara di dunia yaitu Jepang, Papua Nugini, Australia, Cina, Thailand, Kenya, Filipina dan Jepang Sebagian besar menyebutkan bahwa adanya hubungan antara karakteristik iklim dengan kejadian pneumonia pada anak (Brussels. 2010).

Hasil uji statistic dalam penelitian ini menunjukkan tidak adanya hubungan suhu udara dengan kejadian pneumonia, secara teori suhu udara merupakan factor resiko terjadinya pneumonia. Hasil penelitian ini sejalan dengan penelitian Shaharuddin menyebutkan tidak terdapat hubungan yang bermakna antara suhu udara dengan kejadian pneumonia (Leh, Shaharuddin et al., 2016). Suhu udara sangat erat kaitannya dengan pertumbuhan dan perkembangbiakan bakteri penyebab pneumonia, seperti bakteri Streptococcus pneumonia (Mas'udah et al., 2020). 


\section{KESIMPULAN}

Hasil Penelitian yang dilakukan di 12 Kecamatan di Kabupaten Pelalawan Propinsi Riau diketahuui trend kasus Pneumonia pada bulan Januari 2018 sampai Desember 2019 mengalami fluktuasi kurang lebih setiap 2 bulan, hal ini dikarenakan adanya pengaruh musiman yaitu musim hujan dan kemarau. Sebagian besar pada musim hujan jumlah kasus Pneumonia cenderung mengalami trend yang meningkat. Hasil uji statistic dalam penelitian ini menunjukkan curah hujan, hari hujan, kelembaban dan suhu udara tidak signifikan dengan kejadian pneumonia pada balita. Walaupun tidak ada variabel yang signifikan namun nilai R Square pada pemodelan di atas sudah cukup baik yaitu sebesar 0.655 , artinya sebesar $65.5 \%$ keragaman dari Kasus Pneumonia mampu dijelaskan oleh variabel-variabel tersebut sedangkan sisanya dijelaskan oleh variabel lain di luar model.

\section{UCAPAN TERIMAKASIH}

Terimakasih kami sampaikan kepada Pemerintah Kota Pelalawan yang telah memfasilitasi penelitian sehingga penelitian ini berjalan dengan lancar. Kemudian Terima kasih kepada STIKes Hang Tuah Pekanbaru yang telah membantu secara meteri sehingga peneliti dapat menyelesaikan penelitian ini, dan kepada semua pihak telah banyak membantu dalam memberikan sumbangan pemikiran dalam penyelesaian penelitian ini.

\section{DAFTAR PUSTAKA}

Brussels. (2010). Climate Change and Respiratory Disease. Journal European Respiratory Disease. (Impacts of Climate Change on Respiratory Disease).

Chen, C., Wen, H., \& Chen, P. (2012). Prenatal and postnatal risk factors for infantile pneumonia in a representative birth cohort. Epidemiol Infect, 12771285.

https://doi.org/10.1017/S0950268811001890

Ernyasih, Fini, F \& Noor, L. (2018). 'Analisis Hubungan Iklim ( Curah Hujan, Kelembaban , Suhu Udara dan Kecepatan Angin ) dengan Kasus ISPA di DKI Jakarta'. Ilmu Kesehatan Masyarakat, 07(03), 167-173.

Gardinassi. Luiz et all. (2012). Seasonality Of Viral Respiratory Infections In Southeast Of Brazil: The Influence Temperature And Air Humidity. Brazilian Journal of Microbiology : Vol 98 No 108.

Geberet, A., Alemayehu, W \& Yemane, B. (2015). Factors associated with acute respiratory infection in children under the age of 5 years : evidence from the 2011 Ethiopia Demographic and Health Survey. Pediatric Health, Medicine and Therapeutics, (6), 9-13. https://doi.org/10.2147/PHMT.S77915

Goel, V., S, A, Hogade \& SG. Karadesai. (2012). Ventilator Associated Pneumonia in a Medical
Intensive Care Unit Microbial Aetiology, Susceptibility Patterns of Isolated Microorganisms and Outcame. Indian Journal of Anaesthesia, Vol 56(6) : 558-562. doi: 10.4103/0019-5049.104575

Griffiths, P. L., Balakrishna, N., Rao, S. F., \& Johnson, W. (2016). Do socio-economic inequalities in infant growth in rural India operate through maternal size and birth weight? 4460(2), 154-163. https://doi.org/10.3109/03014460.2015.1134656

Herrera-lara S, Fernández-fabrellas E, Cerverajuan Á, Blanquer-olivas R. (2013). Do seasonal changes and climate influence the etiology of community acquired pneumonia? Arch Bronconeumol. ;49(4):140-5.

Honkinen M, Lahti E, Österback R, Ruuskanen O, Waris M. (2012). Viruses and bacteria in sputum samples of children with community-acquired pneumonia. Clin Microbiol Infect. 18(3):300-7. Available from: http://dx.doi.org/10.1111/j.14690691.2011.03603.x

Harnani, Y., Hamidy, R., Sukendi., Afandi, D. (2020). 'Spatial Analysis of Pneumonia in Todlers Based on Environmental, Individual and Behavior Factors ins Pelalawan Regency Riap Province'. Indian Journal of Forensic Medicine \& Toxicology, October-December 2020, Vol. 14, No. 4

HU, W., Z. Xu \& Tong, S. (2015). 'The geographical co-distribution and socio-ecological drivers of childhood pneumonia and diarrhoea in Queensland', Australia'. Epidemiol Infect, 143, 1096-1104. https://doi.org/10.1017/S095026881400171X

J.G. Ayres. (2009). Climate Change and Respiratory Disease: European Respiratory Society Position Statement. European Respiratory Journal : Volume 34 No 2.

Kumbasari, T. A., Budiyono, \& Nikie, A, Y, D. (2017). 'Perbandingan Kejadian Pneumonia Pada Balita Yang Tinggal Di Dataran Tinggi Dan Dataran Rendah Ditinjau Dari Faktor Iklim Kota Semarang Tahun 2012-2016'. Jurnal Kesehatan Masyarakat, 5(5), 898-905.

Kim J, Kim JH, Cheong HK, Kim H, Honda Y, Ha M, et al. (2016). Effect of climate factors on the childhood pneumonia in papua new guinea: A time-series analysis. International Journal Environmental Research Public Health ;13(2):1-16. doi:10.3390/ijerph13020213

Kementerian Kesehatan Republik Indonesia. Pedoman Penyehatan Udara dalam Ruang Rumah. 2011.

Leh, O, L, H., Shaharuddin, A., Kadaruddin, A \& Yaakob, M, J. (2011). Urban air environmental health indicators: A preliminary set for city of Kuala Lumpur. (April 2016), 1-23. https://doi.org/10.21837/pmjournal.v9.i2.86

Mas'udah, A, F., Pristya, T, Y, R.. (2020). Karakteristik Iklim dan Pneumonia Anak : Sistematic Review.Jurnal Respirologi Indonesia, vol 4 No 1. 
Onozuka D, Hashizume M, Hagihara A. (2009). Im- Saputra, A \& Mirtawati. (2020). Vector Autoregressive pact of weather factors on Mycoplasma pneumoniae pneumonia. Thorax ;64(6):507-11. Integrated (VARI) Menggunakan Software R. Jurnal Baut \& Manufaktur, Vol 02, No 01, 09-16.

Onozuka D, Chaves LF. (2014). Climate variability Utami, H.T., \& Windraswara, R. (2019). Korelasi and nonstationary dynamics of mycoplasma pneu- Meteorologi dan Kualitas Udara dengan moniae pneumonia in Japan. PLoS One.;9(4):e95447. nal.pone. 0095447. DOI: $10.1371 /$ jourPneumonia Balita di Kota Semarang Tahun 20132018. Higeia Journal of Public Health Research and Development, 3(4), 588-598. WHO. (2016). Pneumonia. 